Mirela Alushllari*, Nikolla Civici

University of Tirana, Institute of Applied Nuclear Physics, Tirana, Albania
Short Communication ISSN 0351-9465, E-ISSN 2466-2585 UDC: $631.416 .8: 669.4$ doi: $10.5937 /$ zasmat1903297A

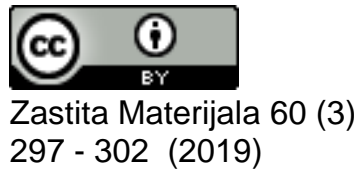

\title{
Identification of lead concentration in soil samples
}

\begin{abstract}
Lead is widely used in industry for building construction, lead-acid batteries, bullets, shot, etc. Lead poisoning is an important environmental pollutant that can have life-long adverse health effects. Lead causes symptoms ranging from the loss of neurological function to death depending upon the extent and duration of exposure. The current study reports the determination of lead concentration in soil samples, distribution of lead on the surface and its penetration in the profile of soils. For this purpose 21 sampling points at a distance 80-600 m around Former Factory Production of Batteries to Berat, Albania were selected. Soil samples (surface and profile) were collected, and were analyzed using Atomic Absorption Spectrometry for their lead content. The concentration ranges of lead in soil samples collected at different points are compared with the Maximum Contaminant Levels (MCL) specified by the Directive 86/278/EEC. From results obtained the fraction of lead in surface soil samples were in range: $126 \mathrm{mg} / \mathrm{kg}-24207 \mathrm{mg} / \mathrm{kg}$. Hazardous Quoted (HQ) for each point sampling was calculated. The level of lead in the profile of worked soil samples, in the depth $20-30 \mathrm{~cm}$ has decreased compared to the concentration of lead concentration in surface soil samples.
\end{abstract}

Keywords: lead, surface and profile soil samples, Atomic Absorption Spectrometry (AAS).

\section{INTRODUCTION}

Lead is not essential element beneficial to humans, animals and plants also it was known as one of the most toxic heavy metals in the environment $[1,2]$. Lead tends to accumulate in the environment: in soil, seawater, fresh water and in sediments $[3,4]$. Lead continuously transferred between air, water and soil by natural processes, physic-chemical such as erosion, precipitation, dry deposition of dust etc. Its exposure in the environment results in a wide range of negative effects, depending from the level of lead and time of extended. Since lead is mostly used for the production of batteries, the major pollution comes exactly from this industry. In general, areas close to Factory of Battery Production are presented with environmental problems, due to increased production and consumption of lead from vegetation and livestock.

\footnotetext{
${ }^{*}$ Corresponding author: Mirela Alushllari

E-mail:m.alushllari@gmail.com

Paper received: 18. 12. 2018.

Paper corrected: 20. 05. 2019.

Paper accepted: 25. 05. 2019.

Paper is available on the website:

www.idk.org.rs/journal
}

As a result, the contamination of soils has influence on the increase of the level of lead in vegetation [5]. The high levels of exposure to lead result in biochemical and toxic effects on the people, causing problems on acute or chronic damage and physical and psychological in capabilities on people [6]. The purpose of this study is: define of lead concentration in surface and profile soil and distribution of lead in surface and profile soils around the former Factory of Battery Production-Berat. The complex of Factory for the production of batteries in Berat, Albania has begun its activity in 1970. It was designed not only to produce batteries for passengers' cars and trucks, but also other military and technical equipment. This factory operated at full capacity until 1997. The Battery Factory conducted its activity as a state-run factory for about 20 years. One of the methods for determination of the total contents of heavy metals of their environmental concentrations is Atomic Absorption Spectroscopy (AAS). In this paper we present determination of lead in soil by AAS method. The level of $\mathrm{Pb}$ in soil samples was compared to the values recommended by the European Community according to Directive 86/278 EEC [7] and was calculated the potential of risk Hazardous Quoted (HQ) by USEPA [8]. 


\section{MATERIAL AND METHOD}

Analysis of this study was performed in the Institute of Applied Nuclear Physics, University of Tirana, Albania. Both representative soil samples depth and area were collected around the street ex-Battery Production Factory-Berat. This Factory is located in the northeastern city of Berat, with respective coordinate: $40^{\circ} 42^{\prime} \mathrm{N}$ and $19^{\circ} 59^{\prime} \mathrm{E}$. During the sampling we have chosen 21 stations and we have collected a total 28 surface and profile soil samples in this area. 21 samples representing are collected at the surface soil $(0-5 \mathrm{~cm})$ for each sampling point, while 7 samples representing at the three sampling points are taken in the depth 15$120 \mathrm{~cm}$. These sampling stations are marked in the map (Figure 1), while their coordinates are presented respectively in table 1 with results.

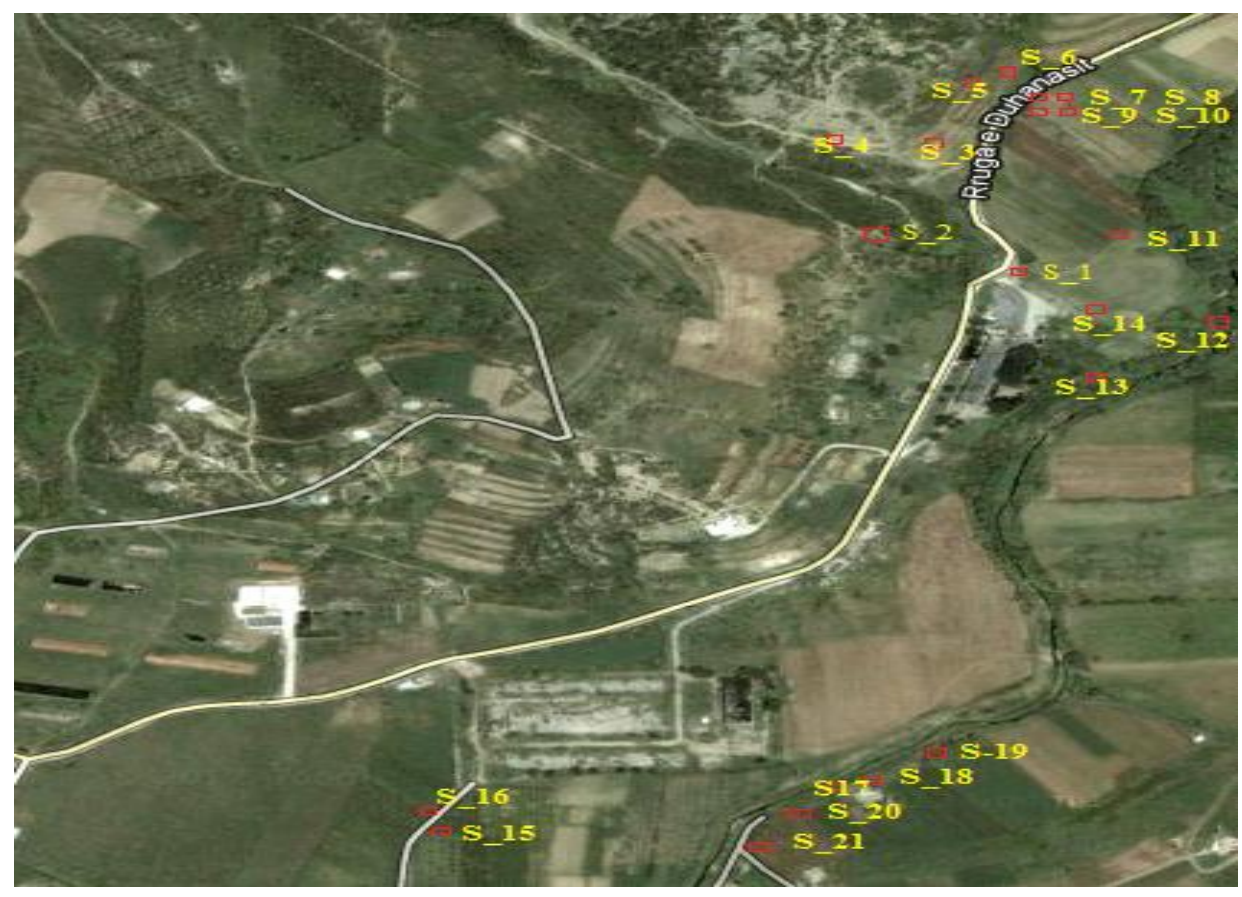

Figure 1. Map of soil sampling stations

Slika 1. Mapa mesta za uzorkovanje tla

Represented soil samples were analyzed using Atomic Absorption Spectrometer, Aanalyst 800 Perkin Elmer with Atomic Absorption Spectrometry, Flame method. Hollow cathode lamp used as radiation source for the determination of lead according recommended conditions. Acids used for the digestion of samples, stock solutions of lead have high grade purity. Glass and Teflon vessels used were treated with solution $10 \% \mathrm{v} / \mathrm{v}$ nitric acid, for 24 hours and then washed with water bidistilled. Both depth and area soil samples are digested according Analytic Method Atomic Absorption Spectrometry. Instrumental conditions for lead are based on Analytical Methods of Atomic Absorption Spectrometry, from Perkin Elmer [9]. Digestion of soil samples are prepared using a procedure recommended by Environmental Protection Agency, it was used as the conventional acid extraction method [8]. About 1 gram of dry soil sample add $10 \mathrm{~mL}$ of $1: 1 \mathrm{HNO}_{3}$, mix the slurry and cover with a watch glass. Heat the sample to $95^{\circ} \mathrm{C}$ $\pm 5^{\circ} \mathrm{C}$ and reflux for 10 to 15 minutes without boiling. Allow the sample to cool, add $5 \mathrm{~mL}$ of concentrated $\mathrm{HNO}_{3}$, replace the cover, and reflux for 30 minutes. If brown fumes are generated, indicating oxidation of the sample by $\mathrm{HNO}_{3}$, repeat this step (addition of $5 \mathrm{~mL}$ of concentration $\mathrm{HNO}_{3}$ ). Heat the sample to $95^{\circ} \mathrm{C} \pm 5^{\circ} \mathrm{C}$ and allow the solution to evaporate to approximately $2-3 \mathrm{~mL}$ without boiling or heat at $95^{\circ} \mathrm{C} \pm 5^{\circ} \mathrm{C}$ without boiling for two hours. It was then transferred quantitatively to a $50 \mathrm{ml}$ volumetric flask by adding distilled water. And finally the solution was filtered [10]. Three applications were carried out for the measurement of calibration standards and measurement of samples. For each element calibration curve equation is linear and passing through point zero. A quality control material IAEA-Soil_7 was analyzed in parallel with the soil samples. To check the instrumental drift, an aqueous standard solution was analyzed after every three samples. 


\section{RESULTS AND DISCUSSIONS}

In the Table 1 is presented results for analyzed samples, (sampling points, code in AAS, coordinates, mean concentration of lead as well as Relative Standard Deviation percentage (\% RSD) and Standard Deviation (SD) in representative soil samples. In addition, from results obtained
Hazardous Quoted [8] for representative surface soil samples have been calculated. Graphs in Figures 2 and 3 show forms of dependence of the content of lead respectively at area and depth of representative soil samples, while in Figure 4 show the variation of $\mathrm{HQ}$ in surface soil samples.

Table 1: Sampling points of soils and concentration of lead, both area and depth soil samples

Tabela 1. Tačke uzorkovanja tla i koncentracije olova, uzorci po površini i dubini tla

\begin{tabular}{|c|c|c|c|c|c|c|}
\hline \multicolumn{7}{|c|}{ Coordinates } \\
\hline Sampling points & Code & North & East & $\mathrm{Pb}(\mathrm{mg} / \mathrm{kg}$ & SD & RSD\% \\
\hline S_1 & P1_T1 & $40^{\circ} 42^{\prime \prime 27.26^{\prime}}$ & $19^{0} 58^{\prime \prime} 59.67^{\prime}$ & 24207 & 11.00 & 18.00 \\
\hline S_1 & P1_T2 & $40^{\circ} 42^{\prime \prime 27.26^{\prime}}$ & $19^{0} 58^{\prime \prime} 59.67^{\prime}$ & 26142 & 0.06 & 11.00 \\
\hline S_1 & P1_T3 & $40^{\circ} 42^{\prime \prime 27.26^{\prime}}$ & $19^{0} 58^{\prime \prime} 59.67^{\prime}$ & 52982 & 9.90 & 3.80 \\
\hline S_2 & $\mathrm{P} 2 \_\mathrm{T} 1$ & $40^{\circ} 42^{\prime \prime} 33.45^{\prime}$ & $19^{0} 58^{\prime \prime} 57.86^{\prime}$ & 350 & 3.00 & 5.60 \\
\hline S_2 & P2_T2 & $40^{\circ} 42^{\prime \prime} 33.45^{\prime}$ & $19^{0} 58^{\prime \prime} 57.86^{\prime}$ & 125 & 14.00 & 11.20 \\
\hline S_3 & P3_T1 & $40^{\circ} 42^{\prime \prime} 34.04^{\prime}$ & $19^{0} 58^{\prime \prime} 53.05^{\prime}$ & 342 & 12.00 & 9.30 \\
\hline S_4 & P4_T1 & $40^{\circ} 42^{\prime \prime} 35.44^{\prime}$ & $19^{0} 58^{\prime \prime} 56.36^{\prime}$ & 244 & 0.20 & 0.80 \\
\hline S_5 & P5_T1 & $40^{\circ} 42^{\prime \prime} 31.29^{\prime}$ & $19^{0} 58^{\prime \prime} 58.87^{\prime}$ & 951 & 28.00 & 1.10 \\
\hline S_6 & P6_T1 & $40^{\circ} 42^{\prime \prime} 31.81^{\prime}$ & $19^{0} 58^{\prime \prime} 9.00^{\prime}$ & 1203 & 22.00 & 1.83 \\
\hline S_7 & P7_T1 & $40^{\circ} 42^{\prime \prime} 31.33^{\prime}$ & $19^{0} 58^{\prime \prime} 58.80^{\prime}$ & 236 & 9.70 & 2.20 \\
\hline S_8 & P8_T1 & $40^{\circ} 42^{\prime \prime} 31.03^{\prime}$ & $19^{0} 58^{\prime \prime} 59.08^{\prime}$ & 228 & 12.00 & 5.26 \\
\hline S_9 & P9_T1 & $40^{\circ} 42^{\prime \prime} 39.38^{\prime}$ & $19^{0} 59^{\prime \prime} 05.72^{\prime}$ & 243 & 9.40 & 12.70 \\
\hline S_10 & P10_T1 & $40^{\circ} 42^{\prime \prime 28.41^{\prime}}$ & $19^{0} 59^{\prime \prime} 02.91^{\prime}$ & 126 & 1.00 & 0.60 \\
\hline S_11 & P11_T1 & $40^{\circ} 42^{\prime \prime 23.70^{\prime}}$ & $19^{0} 59^{\prime \prime} 02.70^{\prime}$ & 460 & 0.30 & 0.10 \\
\hline S_12 & $\mathrm{P} 12 \_\mathrm{T} 1$ & $40^{\circ} 42^{\prime \prime 24.25^{\prime}}$ & $19^{0} 59^{\prime \prime} 00.87^{\prime}$ & 742 & 22.00 & 0.20 \\
\hline S_13 & P13_T1 & $40^{\circ} 42^{\prime \prime 22.67^{\prime}}$ & $19^{0} 58^{\prime \prime} 59.83^{\prime}$ & 384 & 0.40 & 4.90 \\
\hline S_14 & P14_T1 & $40^{\circ} 42^{\prime \prime 24.45^{\prime}}$ & $19^{0} 59^{\prime \prime} 00.96^{\prime}$ & 78 & 0.20 & 0.10 \\
\hline S_14 & P14_T2 & $40^{\circ} 42^{\prime \prime 26.21^{\prime}}$ & $19^{0} 59^{\prime \prime} 01.29^{\prime}$ & 10614 & 3.00 & 0.60 \\
\hline S_15 & S15_T1 & $40^{\circ} 42^{\prime \prime} 04.97^{\prime}$ & $19^{0} 58^{\prime \prime} 42.21^{\prime}$ & 341 & 1.11 & 0.33 \\
\hline S_16 & S16_T1 & $40^{\circ} 42^{\prime \prime} 06.07^{\prime}$ & $19^{0} 58^{\prime \prime} 43.86^{\prime}$ & 185 & 2.70 & 1.46 \\
\hline S_16 & S16_T2 & $40^{\circ} 42^{\prime \prime} 06.07^{\prime}$ & $19^{0} 58^{\prime \prime} 43.86^{\prime}$ & 218 & 13.50 & 6.19 \\
\hline S_17 & S17_T1 & $40^{\circ} 42^{\prime \prime} 08.00^{\prime}$ & $19^{0} 58^{\prime \prime} 52.31^{\prime}$ & 1503 & 3.21 & 0.21 \\
\hline S_17 & S17_T2 & $40^{\circ} 42 " 08.00^{\prime \prime}$ & $19^{0} 58^{\prime \prime} 52.31^{\prime}$ & 718 & 6.43 & 0.90 \\
\hline S_18 & S18_T1 & $40^{\circ} 42^{\prime \prime} 08.13^{\prime \prime}$ & $19^{0} 58^{\prime \prime} 53.46^{\prime}$ & 149 & 0.78 & 0.52 \\
\hline S_19 & S19_T1 & $40^{\circ} 42^{\prime \prime} 08.20^{\prime \prime}$ & $19^{0} 58^{\prime \prime} 53.33^{\prime}$ & 163 & 0.94 & 0.58 \\
\hline S_20 & S20_T1 & $40^{\circ} 42^{\prime \prime} 07.25 "$ & $15^{0} 58^{\prime \prime} 52.39^{\prime}$ & 662 & 0.13 & 0.02 \\
\hline S_21 & $\mathrm{S} 21 \_\mathrm{T} 1$ & $40^{\circ} 42^{\prime \prime 05.09 "}$ & $15^{0} 58^{\prime \prime} 59.73^{\prime}$ & 187 & 16.30 & 8.72 \\
\hline S_21 & S21_T2 & $40^{\circ} 42 " 05.09 "$ & $15^{0} 58^{\prime \prime} 59.73^{\prime}$ & 193 & 8.90 & 4.61 \\
\hline
\end{tabular}




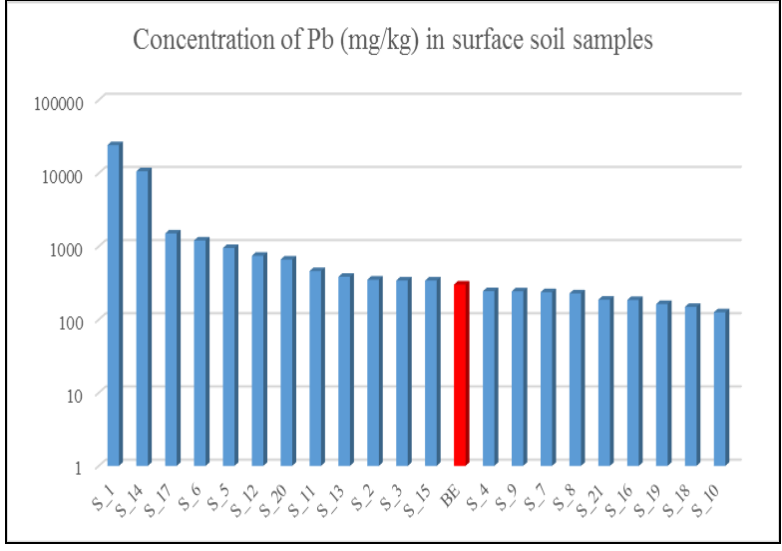

Figure 2: Variation of $\mathrm{Pb}$ concentration in surface soil samples

Slika 2. Varijacija koncentracije Pb u uzorcima površinskog zemljišta

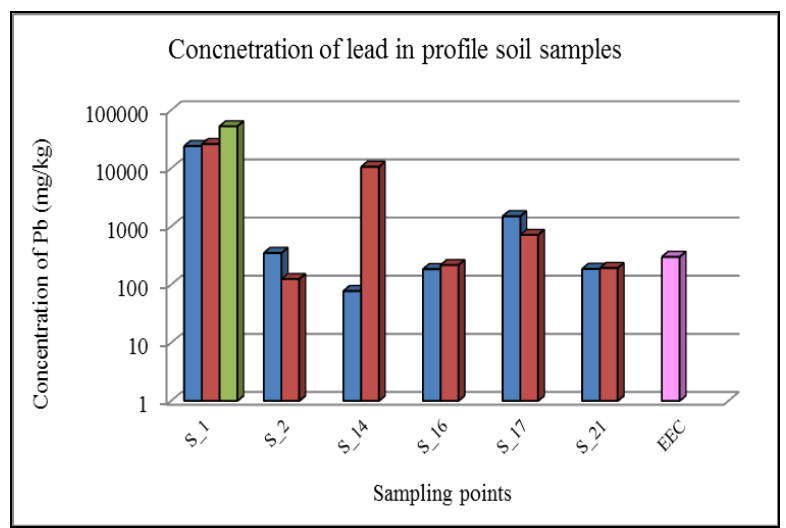

Figure 3: Variation of $\mathrm{Pb}$ in profile soil samples

\section{Slika 3. Varijacije Pb u uzorcima profila tla}

From results obtained it could be observed that lead concentration is not uniquely distributed. The fraction of lead in surface soil samples was found in the order $126 \mathrm{mg} / \mathrm{kg}-24207 \mathrm{mg} / \mathrm{kg}$ (Figure 2). The highest concentration of lead was found in samples collected in S 1 and $S 14$ points. In this territory were throwing wastes in uncontrollable way and is thought to be mixed solid waste of factory with soil. Areas where samples were collected are not used to plant crops but for livestock feed. By analyzing profile samples in these points the lead concentration was higher than surface. By analyzing profile soil samples that were collected at cultivated soils it was observed in general, that concentration of lead has a trend to go down depending on the depth (Figure 3 ). In the Figure 4 is presented contour plot of lead concentration against coordinates of samples point, while in Figure 5 is presented probability plot of lead concentration in soil samples.

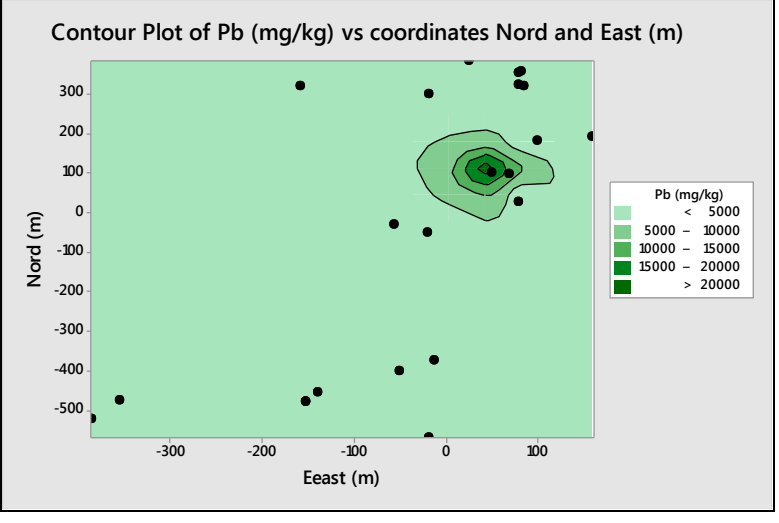

Figure 4: Contour plot of $\mathrm{Pb}$ vs. coordinates N\&E

Slika 4. Skica konture $\mathrm{Pb}$ u odnosu na koordinate N\&E

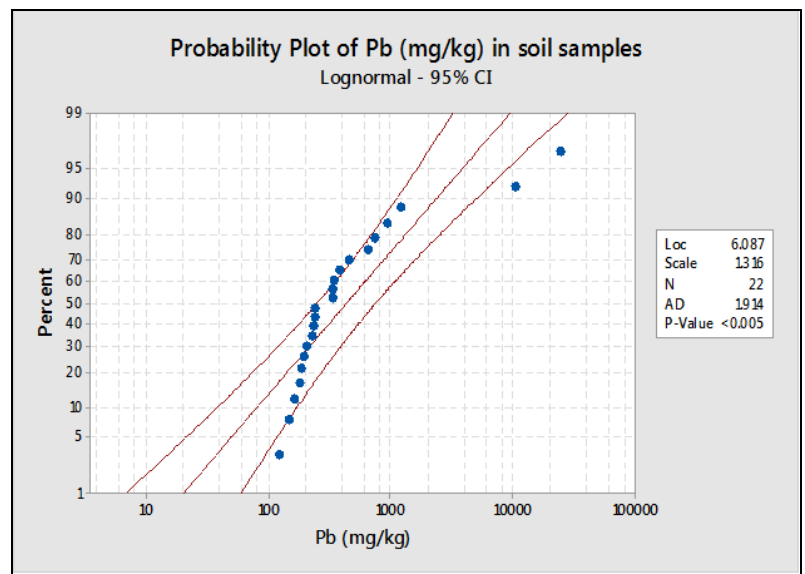

Figure 5: Probability plot of $\mathrm{Pb}$ in soil samples

\section{Slika 5. Grafikon verovatnoće Pb u uzorcima tla}

The dependence of lead concentration from distance of factory is presented in Figure 6 . The mean concentrations of lead in soil samples that are collected at different points during the street from Factory are compared with the Maximum Contaminant Levels (MCL) specified by the Directive 86/278/EEC [11]. Maximal concentration of lead in soil recommended by the Directive $86 / 278 /$ EEC is $300(\mathrm{mg} / \mathrm{kg})$. The calculated Hazardous Quoted for surface soil samples is presented in Table 2. The factor of calculated Hazardous Quoted, HQ in representative soil samples was found in the order 0.4-80 (Figure 7). From 21 surface sampling points 12 of them were found calculated Hazardous Quoted higher than normal. Hazardous Quoted for surface soil samples is higher than 1 , which means that this territory is contaminated and this pollution is associated with the high negative ecological and human effects $[12,13]$. 


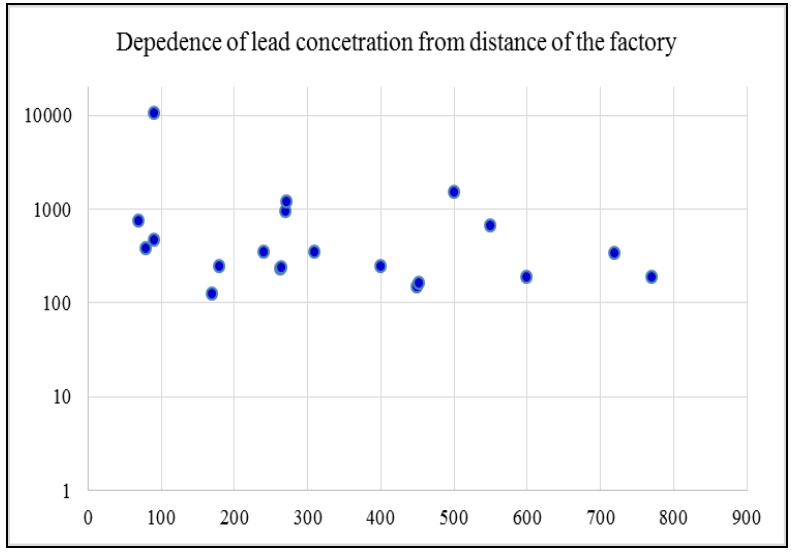

Figure 6: The distribution of lead in the distance

Slika 6. Raspodela olova na daljinu

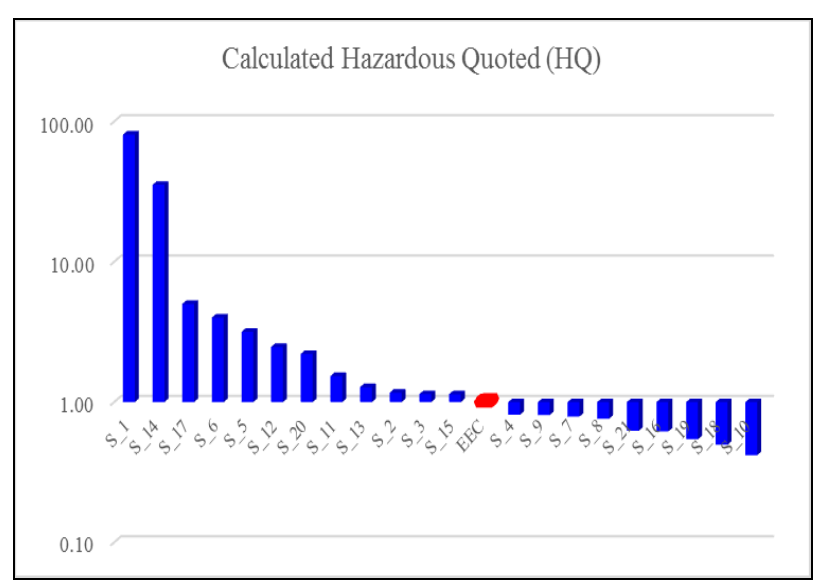

Figure 7: Variation of $H Q$ in surface soil

Slika 7. Varijacija HK-a na površini tla

\section{CONCLUSION}

During this investigation the level of fraction of lead was found to be present in all of the representative soils samples that analyzed. Also, lead was found present in to the profile of soil, (in the depth $20-120 \mathrm{~cm}$ ).

The level of lead in the profile soil samples (in the depth of $20-25 \mathrm{~cm}$ ) collected in the cultivated areas has decreased compared to the concentration of lead in surface soil samples.

In uncultivated areas the concentration of lead in profile soil was higher than the surface soil (mixed waste from factory with soil).

From the results obtained for 12 soil samples contained lead concentration above the MCL, recommended by Directive 86/278/EEC for concentration of lead in soil. In these points the calculated Hazardous Quoted was high.
In general, lead concentration in representative soil samples was present as a result of the contribution of anthropogenic sources, especially uncontrolled waste disposal around area after interruption of Factory activity.

\section{Acknowledgement}

This research is a part of the PhD thesis. During this paper are presented the results obtained for soil samples of (Sampling III). All environmental samples for the doctorate work are performed and completed at University of Tirana, Institute of Applied Nuclear Physics, Department of Instrumental Analytical Methods, Atomic Absorption Spectrometry's Laboratory.

\section{REFERENCES}

[1] A.Demayo, M.C.Taylor, K.W.Taylor, P.V.Hodson (1982) Toxic effects of lead and lead compounds on human health, aquatic life, wildlife plants, and livestock, Critical Reviews in Environmental Control, 12,257-305.

[2] M.Alushllari, N.Civici (2015) Lead concentration in soil inside the area of former battery production factory, Berat, Albania, Zastita materijala, 56(2), 151-155.

[3] A.Zayed, C.M.Lytle, J.H.Qian, N.Terry (1998) Chromium Accumulation, Translocation and Chemical Speciation in Vegetable, Crops.Planta, 206, 293-299.

[4] M.Alushllari, S.Mico (2015) Analyses of heavy metals in the superfical water of lakes, Zastita materijala, 56(4), 492-495.

[5] S.F.Zakrzewski (2002) Environmental Toxicology. 3Rd Edition.Oxford University Press. USA, p.5- 45.

[6] L.N.Aigbedion (2005) Environmental Pollution in the Niger Delta, Nigeria. Inter Disciplinary J. Enugu Niger., 3(4), 205-210.

[7] EEC, Economic European Communities (2006) Setting maximum levels for certain contaminants in foodstuffs. Official Journal European Communities, L 364/5-L 364/24, Directive No. 1881/2006, Brussels.

[8] U.S. EPA. (Environmental Protection Agency) (2006) Risk Assessment Guidance for Superfund Volume I: Human Health Evaluation Manual (Part E, Supplemental Guidance for Dermal Risk Assessment), Final. EPA/540/R/99/005. Office of Solid Waste and Emergency Response, Washington, DC. PB99-963312.

[9] Perkin-Elmer Corp. (1991-1999) Perkin-Elmer Corp.: 1964-2000, Analytical Methods for Atomic Absorption Spectrophotometry. 
[10] EPA, Method 3050B., http://www.epa.gov/osw/ hazard/testmethods/sw846/pdfs/3050b.pdf

[11] EEC, Economic European Communities. (2006). The Council Directive 86/278/EEC on tection of the environment
[12] https://journals.plos.org/plosone/article?id=10.1371/j ournal.pone.0172517

[13] https://www.hindawi.com/journals/jchem/2015/2976 86/

\section{IZVOD}

\section{IDENTIFIKACIJA KONCENTRACIJE OLOVA U UZORCIMA TLA}

Olovo se široko koristi u industriji za izgradnju građevina, baterija sa olovnim pločama, metaka, itd. Olovo je važan zagađivač životne sredine, koji može imati štetne štetne posledice po život. Olovo izaziva simptome u rasponu od gubitka neurološke funkcije do smrti u zavisnosti od obima $i$ trajanja izloženosti. Ova studija izveštava o utvrđivanju koncentracije olova u uzorcima tla, distribuciji olova na površinu i njegovom prodiranju u profil tla. U tu svrhu je odabrano 21 mesto uzorkovanja na udaljenosti od 80-600 m oko bivše fabrike za proizvodnju baterija u mestu Berata, Albanija. Uzorci tla (površina i profil) su sakupljeni $i$ analizirani pomoću atomske apsorpcione spektrometrije za sadržaj olova. Raspon koncentracija olova u uzorcima tla prikupljenih u različitim tačkama upoređeni su sa maksimalnim nivoima kontaminanata (MCL) navedenim Direktivom 86/278 / EEZ. Iz dobijenih rezultata udio olova u uzorcima površinskog zemljišta bio je u opsegu: $126 \mathrm{mg} / \mathrm{kg}-24207 \mathrm{mg} / \mathrm{kg}$. Nivo olova u profilu obrađenih uzoraka tla u dubini od 20-30 cm smanjen je u odnosu na koncentraciju olova u površinskim uzorcima tla.

Ključne reči: olovo, površine i profili, atomska apsorpciona spektrometrija (AAS).

\section{Short Communication}

Rad primljen: 18. 12. 2018.

Rad revidiran: 20. 05. 2019.

Rad prihvaćen: 25. 05. 2019.

Rad je dostupan na sajtu: www.idk.org.rs/casopis

(C) 2019 Authors. Published by Engineering Society for Corrosion. This article is an open access article distributed under the terms and conditions of the Creative Commons Attribution 4.0 International license (https://creativecommons.org/licenses/by/4.0/) 